\title{
Transition management as a model for managing processes of co-evolution towards sustainable development
}

\author{
René Kemp, Derk Loorbach and Jan Rotmans \\ UNU-MERIT, Maastricht, The Netherlands
}

Key words: Co-evolution, sustainable development, multi-level governance, incrementalism, planning, and goal-oriented modulation

\begin{abstract}
SUMMARY
Sustainable development requires changes in socio-technical systems and wider societal change - in beliefs, values and governance. In this article we present a model for managing processes of co-evolution: transition management. Transition management is a multilevel model of governance which shapes processes of co-evolution using visions, transition experiments and cycles of learning and adaptation. Transition management helps societies to transform themselves in a gradual, reflexive way through guided processes of variation and selection, the outcomes of which are stepping stones for further change. It shows that societies can break free from existing practices and technologies, by engaging in co-evolutionary steering. This is illustrated by the Dutch waste management transition. Perhaps transition management constitutes the third way that policy scientists have been looking for all the time, combining the advantages of incrementalism (based on mutual adaptation) with the advantages of planning (based on long-term objectives).
\end{abstract}

\section{INTRODUCTION}

Sustainable development is about the redirection of development (WCED,1987). It is not about an identifiable end state. Sustainable development is a never-ending process of progressive social change. It involves multiple transitions or system innovations. Each transition is made up of processes of co-evolution involving changes in needs, wants, institutions, culture and practices. In this article we argue that sustainable development requires radical changes in functional systems and changes not only in government policy but also in current systems of governance (the orientation of society and patterns of interaction over collective issues). In our view, the existing policy frameworks with fragmented policy areas are not suited for dealing with social complexity and desired long-term change. Different types of governance are needed: more open, adaptive, and oriented towards learning and experimenting.

Special attention is given to co-evolution, where different subsystems are shaping but not determining each other (relative autonomy). We will argue that a co-evolution perspective is the proper perspective for thinking about governance for sustainable development (Norgaard 1994; Van den Bergh and Stagl 2002; Rammel et al. 2004), and will describe a model of shaping co-evolution processes to sustainability goals, which is transition management.

Correspondence: René Kemp, UNU-MERIT, Keizer Karelplein 19, 6211 TC Maastricht, The Netherlands. Email: r.kemp@merit.unimaas.nl 
Through transition management (developed by Rotmans et al. 2000) alternative social trajectories are explored in an adaptive and anticipatory manner.

The first part of the article examines the notion of sustainable development and its relation with co-evolution. The second part discusses problems of steering, offering suggestions for how problems of distributed control, dissent and political myopia may be overcome through transition management. The model of transition management is illustrated by Dutch waste management policies as an example of reflexive, co-evolutionary steering. The last part compares the model of transition management with other models for policy and governance: planning (relying on control) and incremental politics (relying on small steps and cycles of learning and adaptation). As we will see, in terms of governance, transition management makes use of what Lindblom (1979) calls 'partisan mutual adjustment' but with special attention given to problem structuring, long-term goals and learning about system innovation. It combines the capacity to adapt to change with a capacity to shape change (Rammel et al. 2004) and is concerned with positive goals (collectively chosen by society following a process of problem structuring). The first element adaptivity of systems to their environment - is well-established within the literature on coevolution (looking at resilience), the second element-shaping subsystems and their environmenthas received far less attention. It is on this that this article intends to make a valuable contribution, using the waste management transition in the Netherlands as an example.

\section{SUSTAINABLE DEVELOPMENT AS CO-EVOLUTION}

Following the Brundtland report Our Common Future (WCED 1987) sustainable development came to be defined as redirection of trajectories of change in ways that combine economic wealth, environmental protection with social cohesion. After the initial optimism about win-win opportunities, it is increasingly understood that there are tradeoffs between the three goals in any type of development (at least in the short term) and that each development tosses up new problems for society which must be dealt with by policy (Beck 1994). Car-based transport was once much more clean than horse-drawn carriages which filled the street with horse excrement, giving rise to the occupation of road sweepers, clearing the road for people to walk (Kemp and Soete 1992). These days, we have ozone problems caused by automobiles, congestion problems, noise problems and over a million traffic deaths yearly worldwide. In 2000, 1.26 million people died in road accidents (WHO 2004).

Approaching sustainable development as a continuous process of change means that it cannot be translated into a blueprint or a defined end state from which criteria could be derived and unambiguous decisions be taken to get there (Voss et al. 2006: as a multi-dimensional and dynamic concept sustainable development can neither be translated into the narrow terms of static optimisation nor is it conducive to strategies based on direct control, fixed goals and predictability (Rammel et al. 2004: 1). We face a dynamic process where the starting point cannot be a fixed idea of sustainability but derives from social consensus on what we consider to be unsustainable (Wilkinson and Cary 2002 quoted in Rammel et al. 2004). Sustainability refers to a process and a standard and not to an end state: each generation must take up the challenge anew, determining in what directions their development objectives lie, what constitutes the boundaries of the environmentally possible and the environmentally desirable, and what is their understanding of the requirements of social justice (Meadowcroft 1997: 37).

In sustainability discussions, the term coevolution is frequently used. For instance, Norgaard (1984) sees the solution in a co-evolutionary potential based on diversity in the widest sense (including diversity in governance). A co-evolutionary view indeed is important for thinking about governance for sustainable development for two reasons. First, it accepts that we have cause-effect-cause loops across different scales and systems, with effects becoming causes of other developments ('positive feedback' in systems terms). A good example is the use of cars, which facilitated travel and urban sprawl, and in turn increased the demand for cars. This simple example also shows that people's needs are partly endogenous to other developments. See for instance studies on the co-evolution of perceptions and bounded rationality, which point to the relation between human needs, are partly endogenous and related to a selective environment (Hadfield 
and Seaton 1999; van den Bergh and Stagl 2003). The same is true for policy, which is not independent from economy but a response to problems, pollution for instance, with the policies giving rise to new problems (high costs or waste). Second, very paradoxically, a co-evolutionary perspective sees developments in different subsystems as partially independent. Co-evolution is a special type of interdependency: $A$ influences but does not determine $B$ and $C$, which in turn influence but do not determine $A$, although both $\mathrm{A}, \mathrm{B}$ and $\mathrm{C}$ change irreversibly. The different units of evolution enjoy relative autonomy in development. Technical change coevolves with institutional change (within systems of governance and organizations and culture), they are shaping but not determining each other.

In the literature on societal change different types of co-evolution have been noted: supply and demand (Nelson and Winter 1982); technology and users (von Hippel 1988; Leonard-Barton 1988); technology, industry structure and institutions (Nelson 1994; Rosenkopf and Tushman 1994;); actor and structure (Giddens 1984); technology and society (Rip and Kemp 1998; van de Ven and Garud 1994; von Tunzelmann 2001); and ecology, economy and society (Norgaard 1984; Kemp and Soete 1992; Gowdy 1994; Kemp and Rotmans 2005).

Obviously, not every type of interaction should be called co-evolution. Strictly speaking, coevolution occurs when two evolutionary processes are interlinked (van den Bergh and Stagl 2003) but as some people will say that processes with teleological elements (as in human/social evolution) cannot reasonably be viewed as evolutionary (because in economic evolution there is purpose and no gene type), we propose to use the definition of relative autonomy. The co-evolution idea has been taken up by many authors outside biology but the management and governance aspects remain underdeveloped. Useful attempts at that are provided by Lee (1993), Rammel and van der Bergh (2003), Rammel et al. (2004) and Bleischwitz (2004). These co-evolutionary approaches all build on the model of punctuated equilibrium in which periods of slow change are punctuated by periods of radical change. This means that in evolution we have panarchy (Gunderson and Holling 2002) or transitions (Rotmans et al. 2001; Geels 2002, 2005), transitional shifts from one dynamic equilibrium to another. Transitions in society or societal subsystems are the outcome of processes of coevolution in the above sense (Rotmans et al. 2001). In transition terms we speak of co-evolution if the interaction between different societal subsystems influences the dynamics of the individual societal subsystems, leading to irreversible patterns of change. Within the context of transitions coevolution has been dealt with partially: e.g. coevolution between science and technology, between culture and technology and between technology and society (Geels 2002). However, a comprehensive study of co-evolution in broad societal transitions is lacking (Rotmans 2005).

\section{TRANSITION MANAGEMENT FOR SUSTAINABLE DEVELOPMENT}

The co-evolutionary perspective provides a fertile ground for thinking about policy and governance in the context of sustainable development. It implies that straightforward planning as well as incremental strategies are insufficient because these are not able to tackle system failures underlying persistent problems in an adequate manner, leading to suboptimal solutions. To bridge the gap between top-down planning and bottom-up incrementalism, the Dutch model of transition management appears useful. The model of transition management tries to utilize innovative bottom-up developments in a more strategic way by coordinating different levels of governance and fostering self-organization through new types of interaction and cycles of learning and action for radical innovations offering sustainability benefits. Transition management views societal change as a result of the interaction between all relevant actors on different societal levels within the context of a changing societal landscape. It is thus concerned with the use and coordination of interaction and coevolutionary processes.

Transition management is developed as a model for governance based on a number of principles and instruments described below. Before we describe them we should first discuss key problems in managing processes of societal change. The problems are common problems for any type of steering. The novelty of transition management is that it sets out to deal with them in an integrated way, something that is important for sustainability transitions. 


\section{Problem 1: Dissent}

Complex societal problems related to sustainability are characterized by dissent on the ranking of goals, means and nature of the problem. Different people have different perspectives on the (nature) of the problem and preferred solutions. For example, there is no consensus on what sustainable energy or agriculture means in real practical terms. For some biological agriculture is sustainable; for others the larger land requirements of biological farming makes it not sustainable in a global context. Each option has its own setbacks. Over and above this, there is uncertainty about long-term systemic impacts. A proximate solution for this is: continuous and iterative deliberation and assessment in a well-organized discourse; even when there is dissent about appropriate solutions, it may be possible to come to define key parameters for a future system, such as that a sustainable energy system is reliable, affordable and $\mathrm{CO}_{2}$-low. Other parameters could be added, such as that there should be no biodiversity loss (relevant for bioenergy). Problem structuring methods (Rosenhead and Mingers 2002) may be used for getting to a shared problem definition about the current system (the non-sustainable aspects). Assessment of long-term systemic impacts of various sociotechnical options may lead to at least a better understanding of systemic impacts. Through such assessments visions of sustainability may be revised or made more concrete.

\section{Problem 2: Distributed control}

In pluricentric societies control cannot be exercised from the top (Mayntz 1994; Pierre 2000). Control is distributed over various actors with different beliefs, interests and resources. Influence is exercised at different points, also within government, which consist of different layers and silos, making unitary action impossible (Eising and Kohler-Koch 1999). The distributed nature of control calls for cooperation and network management. Current modes of network management are not equipped for long-term structural change. They are too little concerned about long-term substantive ends and too much with the process itself. We need another form of network management which is concerned with expressing long-term aims and the management of transition processes. The essence of transition management is that substance and process go hand-in-hand, creating partisan mutual adjustment against long-term transition goals. The formulation of joint visions and common goals helps actors to coordinate their actions. Different visions are explored by different actors representing different interests.

\section{Problem 3: Determination of short-term steps}

It is unclear how long-term structural change may be achieved through short-term steps. Short-term action for long-term structural change present a big problem to policy-makers. There exists little theory on this. Here we propose a dual strategy of forward reasoning and backward reasoning. The reasoning forward would first be based on trend analysis and forecasting exercises. Second, reasoning forward consists of the identification of useful steps, shortterm actions which generate useful lessons and facilitate further change. Experiments can be used to learn about user satisfaction concerning a range of technical issues. They help to identify problems and to create networks for cooperation (Kemp et al. 1998; Hoogma et al. 2002). Back casting may help to identify strategic experiments and help to set goals for new socio-technical systems. Integrated systems analysis may help to identify pathways, help identify robust options, and help set goals (Rotmans 1998).

\section{Problem 4: Danger of lock-in}

There is a danger that one gets locked in to particular solutions that are not optimal from a longerterm perspective. For example, by choosing the best available option at the beginning of a transition process while other options are still in development, the chances are that future development will be dominated by that specific option. An example is the fossil-based energy system, which is now difficult to transform since infrastructures, regulation and institutions are all in support of that specific option. A way to avoid the danger of getting locked into sub-optimal solutions from a sustainability perspective is the development and use of a portfolio of options (Kemp et al. 2005). When there is a lot of uncertainty about which option is best this is a good strategy, which is widely practiced in business. Support for options could be based on promises and specific benefits for the nation or region in 
which it is used. The support should be regularly reviewed and adapted.

\section{Problem 5: Political myopia}

From historical studies (Geels 2005) we know that transitions in socio-technical systems take one generation or more and thus span various political cycles. Transition management in some way must survive short-term political changes. There is no simple solution for this except that policy-makers and politicians have to accept that a transition takes one generation or more and be willing to wait for long-term results. For this to happen they have to be convinced that a problem needs fundamental change and that time is needed for such a change to occur. The transition arena (Loorbach and Rotmans 2006) is proposed as an instrument that can be used when the sense of urgency is relatively high. The transition arena forms the context in which the focus is on the long term and on in-depth analysis of the problem at hand with a discourse about preferred long-term development. By creating a transition arena outside the regular political short-term cycles, more innovative and radical solutions can emerge as well as novel coalitions and consensus decisions. The structural change process should then be institutionalized through the development of transition agendas, new coalitions and rules and laws and be made adaptive to deal with changing circumstances and political wishes (co-evolution). From this, the following strategies emerge as useful for managing sustainability transitions: problem structuring, participatory integrated assessment, complex systems analysis, vision development, portfolio management, iterative decision-making and adaptive policy, experiments, cooperation, and commitment to transitions. They help to alter regimes of governance and nested hierarchies in the provision of goods and services through processes of variation and selection - of beliefs, concepts, artifacts and institutions.

For changing the order and direction of society and managing transitions of societal systems, a form of multi-level governance is needed in which the above elements are integrated in some way. The way in which this is done in transition management is through the interaction between three levels (Loorbach 2004):
1. Strategic level: processes of vision development, strategic discussions, long-term goal formulation, etc.

2. Tactical level: processes of agenda building, negotiating, networking, coalition building, etc.

3. Operational level: processes of experimenting, project building, implementation, etc.

The processes and outputs of the processes differ at each level (visions, strategies, agendas, projects) and 'co-evolve' throughout the process. Transition management relies on the interaction between processes at three levels. Transition management tries to align these processes through a combination of network governance, self-organization and process management leading to modulation of ongoing dynamics. At each level, specific types of actors participate, specific (policy) instruments are used and different competencies are needed. Transitions are the outcome of the interactions between actors on one level and interactions between levels (see Figure 1).

Operationally, transition management consists of four different clusters of activities: the strategic transition arena (problem structuring and vision development), tactical transition coalitions and networks (agenda building, transition paths), operational-level experiments and projects and finally the monitoring and evaluation of progress (both in terms of process as well as content), leading to adaptation (see Rotmans et al. 2001; Loorbach and Rotmans 2006). This helps to deal with the issue of distributed control because every actor is 'managing' or influencing at least some part of the system. Through a process of partisan mutual adaptation against collectively chosen goals new interaction patterns, policies and socio-technical trajectories emerge in a self-organised manner rather than through steering from the top.

Transition management can be considered as a specific form of multi-level governance (Scharpf 1994, 1999; Hooghe and Marks 2001) whereby state and non state actors are brought together to co-produce and coordinate policies in an iterative and evolutionary manner on different policy levels, adhering to the aforementioned principles. Transition management tries to improve the interaction between different levels of government for the sake of certain transitions. Transition management thus 


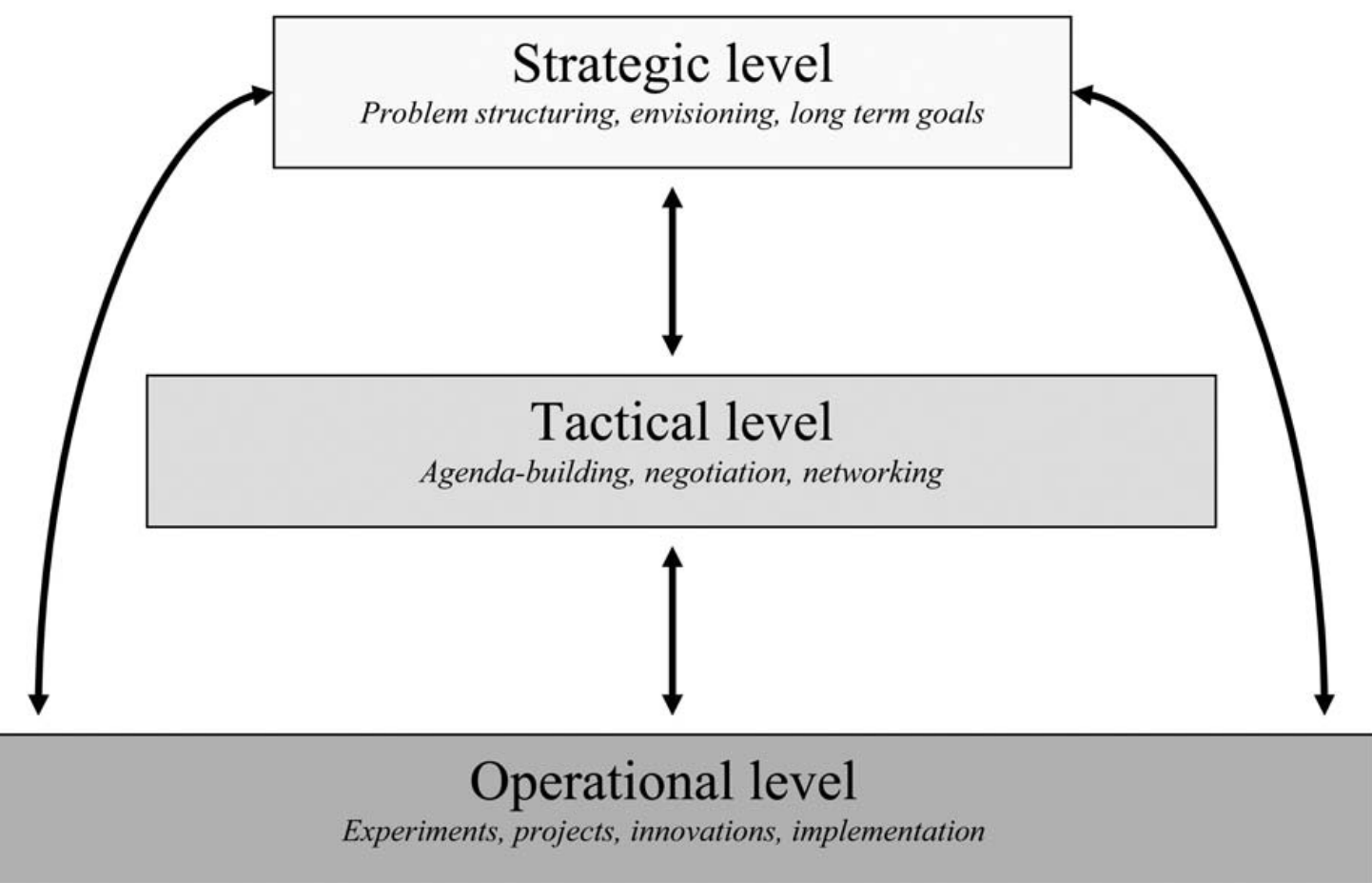

Figure 1 Multilevel approach to transition management

offers a framework for policy integration with the following types of policies:

1. Science policy: sustainability assessments of system innovations, studies of past and ongoing transitions, focusing on the role of policy and usefulness of various governance models;

2. Innovation policy: the creation of innovation alliances, R\&D programmes for sustainable technologies, the use of transition experiments, and alignment of innovation policies to transition goals;

3. Sector policy: niche policies (through procurement, regulations or the use of economic incentives), the removal of barriers to the development of system innovations, and formulation of long-term goals and visions to give direction to research and innovation.

In short, the activities of transition management are aimed at influencing, organizing and coordinating processes at different (strategic, tactical, operational) levels so that these processes are aligned and reinforce each other. Transition management is concerned with the co-evolution of technology and society in a broader sense through analyzing interactions and feedbacks between various subsystems and use these insights for creating levers for influencing these subsystems in order to increase the possibility that these subsystems (and thus the system as a whole) move into a more sustainable direction (Rotmans 2005). The subsystems may be functional systems, such as energy and mobility or housing and care, or different domains and levels of government. The space for innovation is opened up and there is less short-termism. Partial solutions are forgone for options offering a greater suite of benefits.

Transition management comes down to dealing with a multiplicity of steering activities by different actors, different mechanisms and different instruments and driving socio-technical activities in a shared and desired direction. Actor roles will change over time endogenously (as part of the development process). For instance, in the course of an energy transition process, oil companies may decide to become energy companies. Transition management will give rise to altered actor-system dynamics, leading to altered actor configurations and altered power constellations and institutional arrangements that form a different selection environment wherein social innovations can mature more easily.

Actually, transition management is a coevolutionary form of governance in the sense that it aims to develop an innovative governance context 
which enables processes of co-evolution. Transition management is about organizing a sophisticated process whereby the different elements of the cyclical transition management process may coevolve: the joint problem perception, vision, agenda, instruments, experiments and monitoring through a process of social learning about radical innovations and new systems.

\section{The transition in the Dutch waste management system}

An example of a co-produced transition is the Dutch waste-management transition (Loorbach et al. 2003). Today around $80 \%$ of the total amount of waste produced is re-used (also through incineration), compared to $49 \%$ in 1985 (in this year the state started collection of waste-related data). The number of landfill sites fell from 450 in 1977 to 34 in 2000. Today all landfills have advanced systems of soil protection and systems of methane extraction. The capacity of incineration increased steadily, from 2.2 Mton in 1980 to 4.9 Mton in 2000.

The transition from a local system of waste collection to a national system of recycling and increased incineration with controlled landfilling as a last resort option is often viewed as the result of policy. Such a view, although not wrong in itself, overlooks that policy itself was heavily influenced by societal events and changes in consumption and production: the growing volumes of waste, the waste scandals in the 1980s and early 1990s, and changes in beliefs (such as the belief that waste is 'a waste of resources' and the belief that landfilling should be done in a hygienic manner and be used as a last resort option) in a period in which environment was very much on the mind of people.

The transition towards better waste management is best understood as a process of co-evolution of the waste management subsystem and societal values and beliefs (a society growing conscious of waste problems and hostile to landfill sites). Waste scandals of polluted sites and dioxins from incinerators brought attention to problems, which helped to close down old incinerators and build better ones. Various waste acts were introduced and a new organization was created for coordinating the actions of waste players, the waste management council, AOO. The AOO was a network organization that brought together the three layers of government (local, provincial and central) and all waste players. The AOO served important coordinating function, acting as a change agent and mediator.

\section{Strategic level}

At the strategic level there was a change in thinking about waste. With the growing environmentalism and discovery of landfilled toxic waste (Vogelmeerpolder and Lekkerkerk) waste and waste management became a political issue. At the end of the 1980s environmental authorities realized that in order to effectively deal with the continuing increases in waste volumes and the negative effects of common waste management practices


Figure 2 PLEASE PROVIDE LEGEND 
(mainly landfilling), long-term, integrated policies were required, replacing fragmented, locally organized management. Central to policy thinking was the 'waste hierarchy' proposed in the parliamentary motion of Ad Lansink in 1979. This hierarchy prioritized between different management options and went from prevention, through re-use (of products), recycling (of materials), incineration (with energy production) and landfilling as the last option. The motion became law in 1986 and was an important cognitive institution (Parto 2005). To achieve such a differentiated form of waste management, waste management had to be organised at a higher scale (Commission Welschen). This important strategic direction of creating a national system of waste management based on the waste hierarchy was incorporated in the first national environmental policy plan (NEP).

\section{Tactical Level}

At the tactical level there were negotiations, changes in market structure and organization of waste management at larger scales (first supra-local then nationwide). A very important event was the creation in 1990 of a new coordinating body (Waste Management Council, AOO), to coordinate policies between the Environment Ministry (VROM), the provinces (IPO) and the municipalities (VNG) and play an important role in the modernization of the waste system. Producer responsibility was introduced and the waste companies organized themselves in new organizations at the national level. The societal actors were willing to cooperate because the waste management subsystem was in a state of crisis due to acute capacity problems, dioxin problems from incinerators and problems of leaking landfills. A new multilevel form of governance was created which could deal with immediate problems in a forward-looking manner. The changes that happened subsequently can be considered as a form of incremental institutionalization, with an acceleration of this process during the 1990s. The creation of new laws and national policies (which in turn were the outcome of changed beliefs and new problem definitions) enabled lower-level changes. Organization of the businesses in the sector was, for example, made possible through the creation of AOO. These two developments combined facilitated the planning of national infrastructures and accordingly implementation and regulation of more differentiated waste policies.

\section{Operational level}

Operational changes consisted in the closing of old landfill sites and incinerators and creation of new ones with controlled disposal and incineration with heat recovery. In 1994 household waste separation was introduced, which also stimulated the environmental (waste) awareness leading to changes in consumer behaviour. This change in behaviour was accompanied by changes in the practices of waste operators and the structure of the waste subsystem. Waste operators had to learn how to accommodate regulatory requirements regarding collection and handling of waste, while deposit depots (milieuperrons) were established to facilitate maximum citizen participation in waste elimination $/ \mathrm{mini}$ mization efforts. In 1994 so-called VAM vats (green boxes for organic waste) were distributed to every household. Differentiated tariffs (Diftar) were introduced by some municipalities to stimulate recovery and re-use. This innovation diffused widely, also thanks to the information services provided by the AOO.

We are not sure whether to call the multilevel developments a process of co-evolution of codynamics, although it is clear that the waste management subsystem changed in co-evolution with changes on a societal level (in governance and beliefs) and in other societal systems (such as energy provision, consumption and production). The evolution of the waste management system was an unfolding process in which new institutions emerged (on top of existing institutions), such as the waste hierarchy and the waste management council AOO, responding to pressing problems in an adaptive and anticipative (forward-looking) manner similar to transition management. A schematic view of the multilevel co-evololution story is given in Figure 2. The process of change was path-dependent and could only be understood that way. Many institutional changes followed each other (the waste laws, the waste hierarchy, professional private companies, creation of the AOO and the view of waste as a waste of resources, with the new waste practices taking away concerns from citizens). 


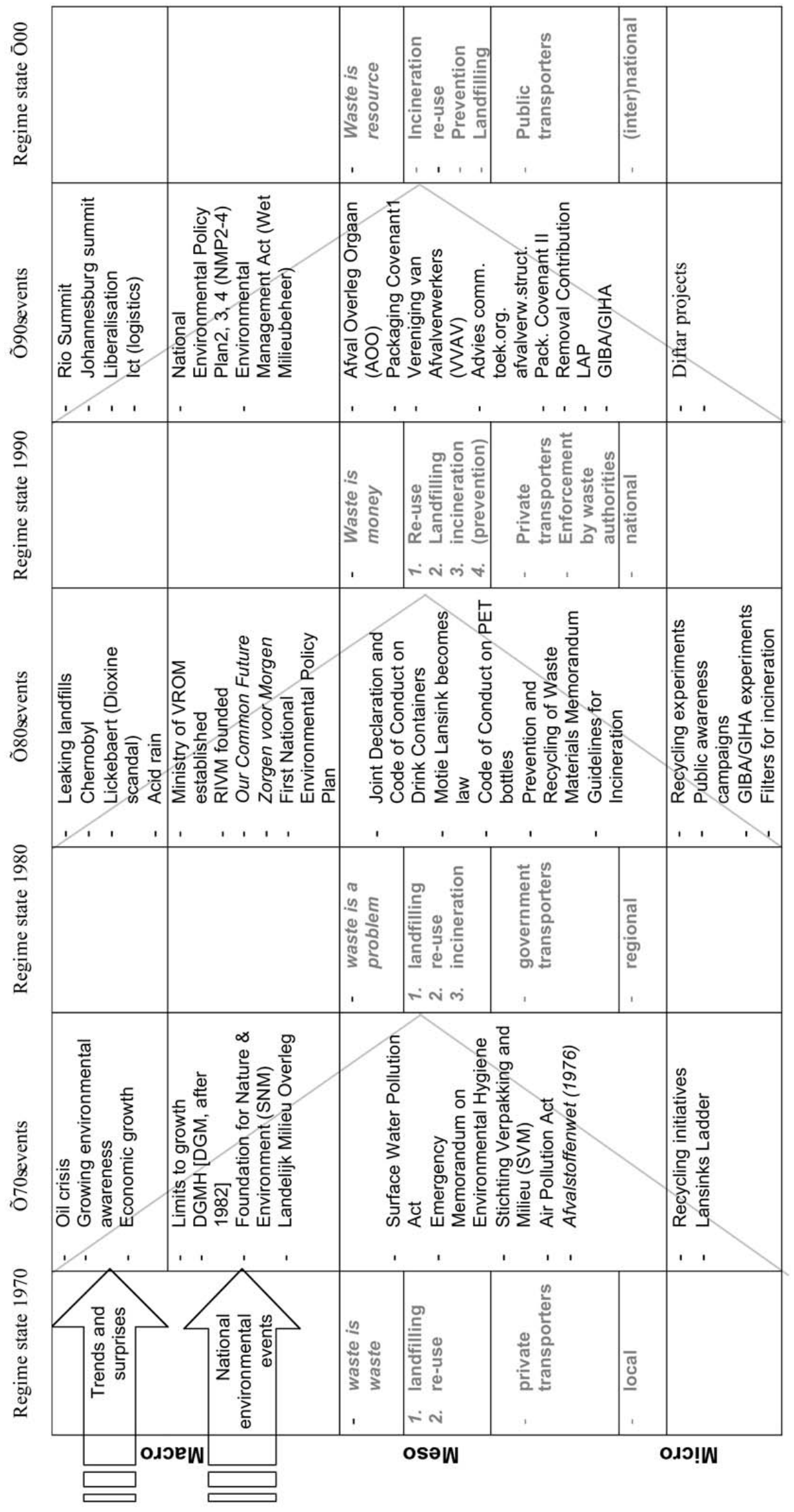

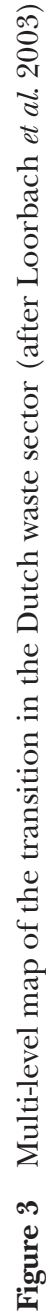




\section{TRANSITION MANAGEMENT AS A THIRD WAY}

Transition management combines elements of long-term planning with incrementalism and relies on markets and network management. We therefore refer to transition management as 'directed incrementalism' (Grunwald 2000), being the English translation of 'Perspektivischer Inkrementalismus'. It is an example of goal-oriented modulation or process management against a set of societal meta-goals using sustainability visions and images. In Table 1 we compare transition management with incrementalism and planning, where we will see that goal-oriented modulation is not a simple mix of the other two models but a distinctive model (in the same way network management was distinctively different from markets and hierarchy as a model of economic coordination).

Transition management uses goals but does not aim to control the future (to use Wildavsky's term).

Table 1 Goal-oriented modulation: between planning and incrementalism

\begin{tabular}{|c|c|c|c|}
\hline & Incrementalism & $\begin{array}{l}\text { Goal-oriented modulation - of which } \\
\text { transition management is an example }\end{array}$ & Planning \\
\hline Key actors & $\begin{array}{l}\text { Private and public } \\
\text { actors }\end{array}$ & Private and public actors, experts & $\begin{array}{l}\text { Bureaucrats and } \\
\text { experts }\end{array}$ \\
\hline Steering philosophy & $\begin{array}{l}\text { Partisan mutual } \\
\text { adaptation, } \\
\text { learning-by-doing }\end{array}$ & $\begin{array}{l}\text { Modulation of developments to } \\
\text { collectively chosen goals, government } \\
\text { is facilitator and mediator }\end{array}$ & Hierarchy \\
\hline Role for anticipation & $\begin{array}{l}\text { Limited (no long- } \\
\text { term goals) }\end{array}$ & $\begin{array}{l}\text { Dynamic, adaptive anticipation of } \\
\text { desired futures as basis for interaction }\end{array}$ & $\begin{array}{l}\text { Future is analysed and } \\
\text { implemented through } \\
\text { blueprint plans }\end{array}$ \\
\hline Type of learning & $\begin{array}{l}\text { First order: learning } \\
\text { about quick fixes for } \\
\text { remedying immediate } \\
\text { ills }\end{array}$ & $\begin{array}{l}\text { Second-order and first-order (rethink } \\
\text { following problem structuring) }\end{array}$ & $\begin{array}{l}\text { First order } \\
\text { (instrumental) }\end{array}$ \\
\hline $\begin{array}{l}\text { Mechanism for } \\
\text { coordination }\end{array}$ & $\begin{array}{l}\text { Markets and emergent } \\
\text { institutionalisation }\end{array}$ & $\begin{array}{l}\text { Markets, network management, } \\
\text { institutionalisation (both designed and } \\
\text { emergent) }\end{array}$ & Hierarchy (top-down) \\
\hline Degree of adaptivity & Adaptive & $\begin{array}{l}\text { Highly adaptive thanks to institutionalized } \\
\text { evaluation and (policy) learning, } \\
\text { portfolios and re-evaluation of goals }\end{array}$ & Hardly adaptive \\
\hline $\begin{array}{l}\text { Role for strategy and } \\
\text { plans }\end{array}$ & Limited role & $\begin{array}{l}\text { Important role for goals and strategic } \\
\text { experiments for exploring social } \\
\text { trajectories, undertaken as part of adaptive } \\
\text { programmes for system innovation }\end{array}$ & Plans with steps \\
\hline $\begin{array}{l}\text { Things against which } \\
\text { policies are evaluated }\end{array}$ & $\begin{array}{l}\text { Individual goals and } \\
\text { short-term gains }\end{array}$ & $\begin{array}{l}\text { Policy goals and learning goals, helping } \\
\text { to determine what to do next }\end{array}$ & Predefined outcomes \\
\hline $\begin{array}{l}\text { Interest mediation/ } \\
\text { conflict resolution }\end{array}$ & $\begin{array}{l}\text { Individual gains for } \\
\text { everyone }\end{array}$ & $\begin{array}{l}\text { Rewards for innovators, phase out of } \\
\text { non-sustainable practices through } \\
\text { markets and politics (collective choice) }\end{array}$ & $\begin{array}{l}\text { Little mediation } \\
\text { (implementation and } \\
\text { enforcement) }\end{array}$ \\
\hline Policy integration & Minimal & Important but typically evolving & Narrow if present \\
\hline $\begin{array}{l}\text { Type of change that } \\
\text { is sought }\end{array}$ & $\begin{array}{l}\text { Incremental, } \\
\text { non-disruptive change } \\
\text { (system improvement) }\end{array}$ & $\begin{array}{l}\text { System innovation (renewal) and system } \\
\text { improvement }\end{array}$ & $\begin{array}{l}\text { Predetermined } \\
\text { outcomes which could } \\
\text { be an improved old } \\
\text { system or a new one }\end{array}$ \\
\hline
\end{tabular}


It relies heavily on market forces and decentralized decision-making. It does not blankly rely on market forces, but is concerned with the conditions under which market forces operate, by engaging in 'context control' so as to orient market dynamics towards societal goals. It consists of government acting to secure circumstances that will maximize the possibilities for progressive social movement by promoting innovation and mitigating negative effects (Meadowcroft 1997: 27). Private initiative is thus not curtailed but rather reoriented towards those activities that serve not only private goals but also serve sustainability goals. This is done through programmes for system innovation and through the use of policy goals providing guidance to societal actors.

Transition management uses advantages of incrementalism. First, it is do-able because it is not disruptive from the viewpoint of special interests; second, the costs of a certain step being a mistake are kept low; third, it allows changing course to prevent lock-in from unwanted solutions; and fourth, useful lessons may be learned informing further steps. Transition management is not a strategy of incremental politics but is rather an incrementalist strategy for changing functional systems towards a more sustainable society. The reason is that, with new technology systems, as with politics, it is impossible to move to the desired state in a straight line since there are too many variables and uncertainties. The best strategy is to take small steps in what is generally perceived 'the right (sustainable) direction,' to try different solutions and to alter course when needed. Like politics, technologies are not born perfect but require adaptation before they constitute a good solution. It is often insufficiently realized that the efficiency of markets rests on the weeding out of sub-optimal designs of products and technologies through market competition (Nelson 1990). Evolutionary change, founded on trial and error, while wasteful in the short term, leads to better outcomes in the long run.

Transition management is different from Lindblom's model of incremental politics and does not opt for disjointed incrementalism, as in the policy analysis method. Integrated problem analysis and complex systems analysis are part of transition management, which is also concerned with positive (sustainability) goals. For this reason it is better viewed as 'logical incrementalism' (Quinn 1978, 1980). Logical incrementalism is a strategy development process where managers have a view of where they want the organization to be in years to come and try to move towards this position in an evolutionary way. They do this by attempting to ensure the success and development of a strong, secure, but flexible, core business, building on the experience gained in that business to inform decisions about the development of the business and using experiments. In transition management there is also a sense of where one want to be in the future, based on collective goals for functional systems, but without specifying the means for fulfilling them. Like incremental politics, transition management opts for steps but the policy steps are chosen to get closer to collectively chosen goals and visions of sustainability.

The use of adaptive, evolutionary steps helps to deal with the criticisms voiced against anticipatory rationality, based on backward reasoning from anticipated consequences. As March and Olsen (1995) write in their book Democratic Governance:

'Too many atrocities of stupidity and immorality have been based on anticipatory rationality and too many efforts to improve human action through importing technologies of decision engineering have been disappointing.' (March and Olsen 1995:198-99)

To them the solution lies in adaptive management, in particular in developing capabilities to respond. They propose the creation of mechanisms capable of organizing experience in the service of improved learning (March and Olsen 1995: 199). In our view, their criticism of anticipatory rationality should probably not be taken as criticism of anticipation or a call for short sightedness but rather as a criticism of a particular method for dealing with the future: strategic planning. A nicely worked-out application of the model of adaptive management is the 'compass and gyroscope' model of Lee (1993) for combining science with politics. Conflict is kept within bounds but is accepted and even viewed necessary. Transition management also tries to keep conflict within bounds, through the orientation to social learning based on problem structuring and strategic experiments (as in the model of Lee).

The steering philosophy is the modulation of ongoing societal developments against a set of collective chosen goals. The various roles of the government are that of initiator, stimulator, facilitator 
and mediator. The structuring form is heterarchy, centralised, cooperative context-steering oriented to producing controlled structural change in which there is modification of structural links and modification of the self-understanding of actors (identities), strategic capacities and interests of individuals and collective actors and hence their preferred strategies and tactics (Jessop 1997: 109-110). Reinstitutionalisation is an important aim of transition management for which it relies on reflexivity (self-confrontation and learning).

In our view, our model of transition management combines the advantages of both types of approaches. It inserts a strategic element in incrementalism and makes planning more adaptive (open with regard to outcomes) and participatory (open to stakeholders). In Table 1 we delineate the key features. From the table it is clear that goaloriented modulation is not a simple mix of incrementalism and planning but has set distinctive features: problem structuring, social learning, portfolios and strategic experiments, transitions arenas for envisioning and institutionalisation of learning and capacity building in government and society. Perhaps it constitutes the third way political scientists have been looking for (cf. Etzioni 1986).

\section{CONCLUSIONS}

In this article we have examined co-evolution aspects of sustainable development, focusing on possibilities for managing processes of co-evolution into a more sustainable direction in a co-evolutionary manner. We examined three approaches for shaping co-evolution: incrementalism (dealing with ills through mutual adaptation) as a bottom-up approach; comprehensive planning as a top-down approach; and transition management as a combined bottom-up and top down approach of goal-oriented modulation. All three approaches are concerned with the normative orientation of societal processes and seek, to different degrees, to overcome the conflict between long-term imperatives and short-term concerns. Based on what we know, incrementalism is useful but by far not enough; experiments with innovative solutions are best pursued as part of a broader approach such as transition management. Overall, transition management is a co-evolutionary steering concept that involves a cyclical process of notions, ideas, instruments and mechanisms that co-evolve: shared problem perception, sustainability vision, agenda, experiments, instruments and monitoring through a process of social learning about radical systemic change offering sustainability benefits besides user benefits.

Transition management employs an integrative and multi-scale framework for policy deliberation, choice of instruments, and actions by individuals, private and public organizations, and society at large. It comprises elements of network management, self-organisation, a perspective-based (guided) form of process management, portfolio management, planning and market coordination. Transition management is inclusive and calls for setting long-term and intermediate goals, alignment of policies short- and long-term policies and strategic experimentation, besides traditional policies. Because it aims for long-term change in functional systems in a gradual manner through variation and selection, it is do-able in a society in which interests are well organized and steering from the top is basically impossible. It is used in the Netherlands for managing the transition to sustainable energy, sustainable mobility, sustainable agriculture, sustainable water use and the biodiversity and natural resource transition.

The presented concept of transition management has been derived from the complex systems approach, new forms of governance and social theory. These management principles have been translated into an operational model. This management concept is both descriptive and prescriptive in the sense that it can be used to analyse as well as to influence transitions. Looking at different levels of governance, the way innovations at each level are organized and developed will provide understanding of their impacts in the context of transition. But perhaps even more importantly, the concept can be used to prescriptively formulate a governance model to select, organize and structure the appropriate governance styles and tools. This governance mix is context-specific, but its general outlines and framework are generic.

Transition management is possibly best described as 'Perspektivischer Inkrementalismus' or directed incrementalism (Grunwald 2000), taking on board criticisms voiced against incrementalism such as lack of orientation, conservatism and negative stance against analysis as noted in Weiss and 
Woodhouse (1992). Transition management builds on processes of co-evolution, which are shaped in a reflexive manner through multilevel processes of variation and selection.

\section{ACKNOWLEDGEMENTS}

We thank the editor and reviewer for very helpful comments on an earlier version.

\section{REFERENCES}

Beck U. The Reinvention of Politics. Towards a Theory of Reflexive Modernization. In Beck U, Giddens A and Lash S (eds), Reflexive Modernization. Politics, Tradition and Aesthetics in the Modern Social Order. Oxford: Polity Press; 1994:1-55

Bleischwitz R. Governance of sustainable development: co-evolution of corporate and political strategies. International Journal of Sustainable Development 2004;7(1):27-43

Eising $\mathrm{R}$ and Kohler-Koch B. The Transformation of EU Governance. London: Routledge; 1999

Etzioni A. Mixed Scanning Revisited. Public Administration Review 1986;Jan/Feb:8-14

Geels FW. Technological transitions as evolutionary reconfiguration processes: A multi-level perspective and a case-study. Research Policy 2002;31 (8/9): 1257-74

Geels FW. System Innovation and the Transition to Sustainability. Theory, Evidence and Policy. Cheltenham: Edward Elgar; 2005

Giddens A. The constitution of society. Outline of the theory of structuration. Cambridge: Polity Press; 1984

Gowdy J. Coevolutionary Economics: The Economy, Society and the Environment. Dordrecht: Kluwer; 1994

Gunderson LH and Holling CS. Panarchy: Understanding transformations in human and natural systems. Washington DC: Island Press; 2002

Grunwald A. Technology Policy between Long-term Planning Requirements and Short-ranged Acceptance Problems. New Challenges for Technology Assessment. In Grin J and Grunwald A (eds), Vision Assessment: Shaping Technology in the 21st Century Society. Towards a Repertoire for Technology assessment. Berlin-Heidelberg: Springer; 2000

Hadfield L and Seaton R. A co-evolutionary model of change in environmental management. Futures 1999;31:577-92

Hooghe L and Marks G. Multi-level governance and European integration. Oxford: Rowman \& Littlefield Publishers; 2001

Hoogma R, Kemp R, Schot J and Truffer B. Experimenting for Sustainable Transport. The Approach of Strategic Niche Management. London: EF\&N Spon; 2002

Jessop B. The Governance of Complexity and the Complexity of Governance: Preliminary remarks on some problems and limits of economic guidance. In Amin A and Hausner J (eds), Beyond market and Hierarchy. Interactive Governance and Social Complexity. Cheltenham: Edward Elgar; 1997

Kemp R and Soete L. The Greening of Technological Progress: An Evolutionary Perspective. Futures 1992;24(5):437-57

Kemp R, Schot J and Hoogma R. Regime Shifts to Sustainability through Processes of Niche Formation. The Approach of Strategic Niche Management. Technology Analysis and Strategic Management 1998;10(2):175-95

Kemp R and Rotmans J. Managing the Transition to Sustainable Mobility. In Elzen B, Geels F and Green K (eds), System Innovation and the Transition to Sustainability: Theory, Evidence and Policy. Cheltenham: Edgar Elgar; 2004:137-67

Kemp R and Rotmans J. The management of the co-evolution of technical, environmental and social systems. In Weber $\mathrm{M}$ and Hemmelskamp J (eds), Towards Environmental Innovation Systems. Berlin-Heidelberg: Springer Verlag; 2005: 33-55

Kemp R, Parto S and Gibson RB. Governance for Sustainable Development: Moving from theory to practice. The International Journal of Sustainable Development 2005;12:13-30

Kenny M and Meadowcroft J. Planning Sustainability. London and New York: Routledge; 1997

Lee KN. Compass and Gyroscope. Integrating Science and Politics for the Environment. Washington DC: Island Press; 1993

Leonard-Barton D. Implementation as Mutual Adaptation of Technology and Organisation. Research Policy 1988;17:251-67

Lindblom CE. Still Muddling, Not Yet Through. Public Administration Review 1979;Nov/Dec:517-26

Lindblom CE. Century of Planning. In Kenny M and Meadowcroft J (eds), Planning sustainability. London and New York: Routledge; 1997:39-65

Loorbach D, Parto S and Kemp R. From Waste Disposal to Waste Management: Transitions in waste management in the Netherlands. Paper presented at the Netherlands Organization for Scientific Research (NWO); May 2003

Loorbach D. Governance and transitions: a multi-level policy-framework based on complex systems thinking. Paper read at Conference on Human Dimensions 
of Global Environmental Change, Berlin, Germany; 2004

Loorbach D and Rotmans J. Managing transitions for sustainable development. In Wieczorek AJ and Olsthoorn X (eds), Industrial Transformation disciplinairy approaches towards transformation research. Dordrecht: Kluwer Academic Publishers; 2006

March JG and Olsen JP. Democratic Governance. New York: The Free Press; 1995

Mayntz R. Governing Failures and the Problem of Governability: Some Comments on a Theoretical Paradigm. I: Kooiman J (ed.), Modern Governance. New Government-Society Interactions. London: Sage; 1994:9-20

Meadowcroft J. Planning for sustainable development: what can be learned from the critics? In Kenny $\mathrm{M}$ and Meadowcroft J (eds), Planning sustainability. London and New York: Routledge; 1997:12-38

Nelson RR. The Co-evolution of Technology, Industrial Structure, and Supporting Institutions. Industrial and Corporate Change 1994;3:47-63

Nelson RR and Winter SG. An Evolutionary Theory of Economic Change. Cambridge MA: Bellknap Press; 1982

Nelson RR. Capitalism as an engine of progress. Research Policy 1990;19(3):193-214

Norgaard R. Coevolutionary Development Potential. Land Economics 1984:60:160-73

Norgaard R. Development betrayed: The end of progress and a co evolutionary revisioning of the future. London: Routledge; 1994

NMP-4. Een wereld en een wil. Werken aan duurzaamheid. (A World and a will. Working on Sustainability). The Hague, the Netherlands; 2000

Parto S. Economic Activity and Institutions: Taking Stock. Journal of Economic Issues 2005;39(1):21-52

Pierre J. Debating Governance. Authority, Steering and Democracy. Oxford: Oxford University Press; 2000

Quinn JB. Strategic Change: "Logical Incrementalism”. Sloan Management Review 1978;fall:7-21

Quinn JB. Strategies for Change: Logical Incrementalism. Homewood: Irwin; 1980

Rammel C, Hinterberger F and Bechthold U. Governing Sustainable Development-A Co-evolutionary Perspective on Transitions and Change. GoSD working paper 1. 2004

Rammel C and van den Bergh J. An evolutionary perspective on policies for sustainable development. Ecological Economics 2003;47(2-3):121-33

Rip A and Kemp R. Technological Change. In Rayner S and Malone EL (eds), Human Choice and Climate Change. Columbus OH: Battelle Press; 1998:vol 2: 327-99
Rosenhead J and Mingers J. Rational Analysis for a Problematic World Revisited: Problem Structuring Methods for Complexity, Uncertainty and Conflict. London: Wiley and Sons; 2002

Rosenkopf L and Tushman M. The Coevolution of Technology and Organization. In: Baum J and Singh J, eds. Evolutionary Dynamics of Organizations. Oxford: Oxford University Press; 1994:403-24

Rotmans J, Kemp R, van Asselt M, Geels F, Verbong G and Molendijk K. Transities $\mathcal{E}$ Transitiemanagement. De casus van een emissiearme energievoorziening. Final report of study "Transitions and Transition management" for the 4th National Environmental Policy Plan (NMP-4) of the Netherlands. Maastricht: ICIS \& MERIT; October 2000

Rotmans J, Kemp R and van Asselt M. More Evolution than Revolution. Transition Management in Public Policy. Foresight 2001;3(1):15-31

Rotmans J. Methods for IA: The challenges and opportunities ahead. Environmental Modelling and Assessment 1998;3:155-79.

Rotmans J. Societal innovation: between dream and reality lies complexity. Inaugural Speech, Erasmus University Rotterdam; 2005

Scharpf F. Community and Autonomy. Multi-Level Policy Making in the EU. Journal of European Public Policy 1994;1:219-42

Scharp F. Governing in Europe: effective and democratic? Oxford: Oxford University Press; 1999

Van den Bergh JCJM and Stagl S. Co evolution of economic behaviour and institutions: towards a theory of institutional change. Journal of Evolutionary Economics 2003;13(3):289-317

Van de Ven AH and Garud R. The Co evolution of Technical and Institutional Events in the Development of an Innovation. In Baum JA and Singh JV (eds), Evolutionary Dynamics of Organizations. New York and Oxford: Oxford University Press; 1994: 425-43

Von Hippel E. The Sources of Innovation. New York: Oxford University Press; 1988

Von Tunzelmann N. Historical co evolution of governance and technology. Presented at the Conference "The Future of Innovation Studies" Eindhoven University of Technology; 20-23 September 2001

Voss J-P, Kemp R and Bauknecht D. Reflexive Governance: A View on the Emerging Path, In Voss JP, Bauknecht D and Kemp R (eds), Reflexive Governance for Sustainable Development. Cheltenham: Edward Elgar 2006;419-38

WCED. Our Common Future. Oxford: Oxford University Press; 1987

Weiss ?? and Woodhouse ??INITIALS??. Reframing Incrementalism: A constructive response to the critics. Policy Sciences 1992;25 (3):255-73 
WHO. World report on road traffic injury prevention. Geneva: WHO; 2004
Wilkinson R and Cary J. Sustainability as an Evolutionary Process. The International Journal of Sustainable Development 2002;5(4):381-91 